\title{
PENAMPILAN PRODUKSI KELINCI PERIODE PERTUMBUHAN YANG DIBERI PAKAN WAFER LIMBAH DAUN UBI JALAR (Ipomoeabatatas) DENGAN PENAMBAHAN BERBAGAI LEVEL MOLASES
}

\author{
A.E.HARAHAP, E. SALEH ${ }^{1}$ DAN N. JANNAH \\ Fakultas Pertanian dan Peternakan Universitas Islam Negeri Sultan Syarif Kasim Riau \\ Jl. H. R. Soebrantas Km 15Simpang Baru Panam Pekanbaru \\ Email : neniannisaharahap@yahoo.co.id
}

ABSTRACT

\begin{abstract}
The aim of this research is to determine of the wafer of performance of rabbits during the growth period given wafer sweet potato leaves waste with various levels of molasses. In The result showed that the treatment in this experiment had no significant effect $(P>0.05)$ on feed consumption, average daily gain, feed conversion. The conclusion of this experiment is that giving molasses to complete ration wafers up to the level of $15 \%$ in the rabbit unable to increase feed consumption (g/head/day), body weight $(\mathrm{g} / \mathrm{head} / \mathrm{day})$ and feed conversion.
\end{abstract}

Keywords: Molases, performance, rabbit, sweet potato leaves, wafers

\section{PENDAHULUAN}

Kelinci adalah salah satu jenis satwa harapan yang memiliki prospek cukup baik. Ternak kelinci memiliki beberapa keunggulan yaitu menghasilkan daging yang berkualitas tinggi dengan kadar lemak yang rendah; tidak membutuhkan areal yang luas dalam pemeliharaannya, dapat memanfaatkan bahan pakan dari berbagai jenis hijauan dan sisa dapur. Pakan kelinci umumnya diberikan dalam bentuk hijauan segar atau hijauan yang telah dilayukan. Kelinci merupakan hewan herbivora non ruminansia yang sebagian besar kebutuhan pakannya berasal dari hijauan. Pakan hijauan yang diberikan untuk pakan kelinci antara lain rumput lapangan, limbah sayuran (kangkung, sawi, wortel, caisim, kol, daun singkong), daun turi, daun lamtoro, daun kembang sepatu, daun kacang panjang, daun ubi jalar, daun kacang tanah, daun dan batang jagung, daun pepaya, talas dan lain-lain (Sarwono dan Arianto, 2007). Hal ini menunjukkan bahwa kebutuhan ternak kelinci akan hijauan lebih besar dari pada konsentrat.
Ketersediaan pakan hijauan meningkat pada saat musim penghujan dan menurun pada saat musim kemarau, sehingga terjadi kekurangan pakan pada saat musim kemarau.

Permasalahan pakan dapat diatasi dengan mencari bahan pakan alternatif yang potensial, murah, mudah diperoleh dan tidak bersaing dengan manusia. Hasil tanaman sampingan pertanian merupakan bahan pakan yang mudah diperoleh dan melimpah. Limbah pertanian merupakan bahan pakan alternatif yang masih memiliki kandungan nutrisi yang baik sehingga dapat digunakan dalam penyusun ransum ternak. Limbah pertanian yang bisa dimanfaatkan sebagai pakan salah satunya adalah limbah ubi jalar (Ipomoea batatas). Menurut Badan Pusat Statistik (2016), produktivitas ubi jalar di Riau mencapai 6.562 ton/ha/tahun yang menyebabkan banyaknya limbah ubi jalar yang belum termanfaatkan dengan baik. Persentase limbah ubi jalar mencapai $60 \%$ dari hasil panen tanaman ubi jalar. Tingginya persentase limbah ubi jalar dapat dijadikan alternatif sebagai pakan. Daun ubi jalar 
merupakan jenis hijauan yang sangat disukai oleh ternak kelinci. Ubi jalar adalah salah satu tanaman palawija sumber karbohidrat. Berdasarkan kandungan karbohidratnya, ubi jalar menduduki peringkat ketiga setelah jagung dan ubi kayu. Selain sebagai sumber karbohidrat, ubi jalar juga mempunyai kadar vitamin $A$ yang tinggi. Kadar vitamin A pada ubi jalar merupakan salah satu indikator warna daging. Daging ubi jalar memiliki kandungan vitamin A yang lebih besar 15 kali dibandingkan dengan wortel, selain itu ubi jalar mengandung vitamin dan mineral seperti niacin, riboflavin, vitamin C, kalsium, besi dan fosfor (Khalil, 2016).

Upaya meningkatkan kualitas mutu pakan, memudahkan penyimpanan serta dapat disimpan dalam waktu relatif lama dibutuhkan teknologi yang dapat mengawetkan pakan, salah satu cara untuk pengawetan pakan yaitu dibuat dalam bentuk wafer. Wafer adalah salah satu bentuk pakan yang merupakan modifikasi bentuk cube, dalam proses pembuatannya mengalami pemadatan dengan tekanan dan pemanasan dalam suhu tertentu (Noviagama, 2002).

Dalam pembuatan wafer diperlukan perekat yang digunakan untuk mengikat komponen-komponen bahan pakan agar mempunyai struktur yang kompak sehingga tidak mudah hancur dan mudah dibentuk pada proses pembuatannya. Salah satu bahan perekat yang dapat digunakan dalam pembuatan wafer adalah molases. Molases adalah cairan kental limbah pemurnian gula merupakan sisa nira yang telah mengalami proses kristalisasi. Keuntungan penggunaan Molases adalah sebagai sumber karbohidrat tinggi (48-60\% gula), kadar mineral cukup dan disukai ternak (Yudith, 2010). Penelitian Retnani dkk. (2009), menyatakan bahwa penggunaan molases 5\% menghasilkan kualitas fisik wafer yang baik hingga lama penyimpanan 4 minggu.

Ransum yang baik tidak hanya memiliki kualitas fisik yang baik, namun juga disukai oleh ternak (palatabilitas). Palatabilitas merupakan gambaran sifat bahan pakan yang dicerminkan oleh organoleptik seperti penampakan, bau, rasa (hambar, asin, manis, pahit), tekstur dan temperaturnya sehingga menimbulkan ransangan dan daya tarik ternak untuk mengonsumsinya (Yusmadi et al., 2008). Pakan yang disukai ternak akan lebih banyak dikomsumsi dibandingkan dengan pakan yang tidak disukai oleh ternak.

\section{METODE PENELITIAN}

Penelitian ini telah dilaksanakan pada bulan Maret sampai April 2018 di Laboratorium Ilmu Nutrisi dan Kimia dan Laboratorium Agrostologi, Industri Pakan dan Ilmu Tanah, Fakultas Pertanian dan Peternakan Universitas Islam Negeri Sultan Syarif Kasim Riau, Pekanbaru.

\section{Bahan dan Alat}

Bahan yang akan digunakan dalam penelitian ini adalah 8 ekor kelinci lokal betina berumur 3-5 bulan, dengan kisaran bobot badan 1000 gram-1400 gram, pakan yang diberikan dalam bentuk wafer yang disusun dari limbah daun ubi jalar, ampas tahu, jagung dan molases.

Peralatan yang digunakan dalam penelitian ini yaitu mesin grinder, baskom, sendok pengaduk, neraca analitik, mesin kempa yang digunakan dalam proses pengepresan pada pembuatan wafer, serta kandang koloni yang setiap kandang memuat 2 ekor kelinci, tempat pakan dan minum, timbangan dan alat tulis. 


\section{MetodePenelitian}

\section{Uji Kualitas Fisik Wafer Ransum Komplit (WRK)}

Pengujian kualitas fisik wafer ransum komplit menggunakan Rancangan Acak Lengkap (RAL) 4 perlakuan yaitu : $\mathrm{T}_{0}, \mathrm{~T}_{1}$, $\mathrm{T}_{2}, \mathrm{~T}_{3}$. Masing-masing perlakuan diulang se 4 kali. Perlakuan penelitian adalah :

$\mathrm{T}_{0}$ :Wafer Ransum Komplit (WRK) daun ubi jalar tanpa penambahan molases

$\mathrm{T}_{1}$ : WRK daun ubi jalar $+5 \%$ Molases
$\mathrm{T}_{2}$ : WRK daun ubi jalar $+10 \%$ Molases

$\mathrm{T}_{3}$ : WRK daun ubi jalar $+15 \%$ Molases

Komposisi nutrisi masing-masing bahan pakan dilihat pada Tabel 1 dan 2 .

\section{Parameter Penelitian}

Parameter yang diamati dalam penelitian ini adalah: konsumsi ransum, pertambahan bobot badan kelinci dan konversi ransum.

Tabel 1. Komposisi ransum perlakuan (dalam kg)

\begin{tabular}{lcccc}
\hline \multirow{2}{*}{ Nama Bahan } & \multicolumn{4}{c}{ Perlakuan } \\
\cline { 2 - 4 } & $\mathrm{T} 0$ & $\mathrm{~T} 1$ & $\mathrm{~T} 2$ & $\mathrm{~T} 3$ \\
\hline Jagung & 40,00 & 35,00 & 30,00 & 25,00 \\
Ampas Tahu & 30,00 & 30,00 & 30,00 & 30,00 \\
Tepung Daun Ubi Jalar & 30,00 & 30,00 & 30,00 & 30,00 \\
Molases & 0,00 & 5,00 & 10,00 & 15,00 \\
\hline Jumlah & 100,00 & 100,00 & 100,00 & 100,00 \\
\hline
\end{tabular}

Sumber : Hasil Perhitungan Ransum

Tabel 2. Kandungan nutrisi ransum perlakuan

\begin{tabular}{cccccc}
\multirow{2}{*}{ Perlakuan } & \multicolumn{5}{c}{ Kandungan Nutrisi } \\
\cline { 2 - 6 } T0 & Protein Kasar(\%) & Lemak Kasar (\%) & Serat Kasar $(\%)$ & Ca $(\%)$ & $\mathrm{P}(\%)$ \\
\cline { 2 - 6 } T1 & 16,46 & 4,92 & 10,54 & 0,30 & 0,56 \\
T2 & 16,09 & 5,03 & 10,57 & 0,33 & 0,50 \\
T3 & 15,72 & 5,13 & 10,40 & 0,37 & 0,43 \\
& 15,32 & 5,24 & 10,33 & 0,40 & 0,37
\end{tabular}

Sumber : Hasil Perhitungan Ransum

\section{HASIL DAN PEMBAHASAN}

\section{Konsumsi Ransum}

Konsumsi ransum adalah faktor dasar untuk hidup dan menentukan produksi (Parakkasi, 1999). Faktor-faktor yang memengaruhi konsumsi ransum pada ternak kelinci adalah temperatur lingkungan, kesehatan, bentuk ransum, imbangan zat makanan, cekaman, bobot badan, dan kecepatan pertumbuhan (NRC, 1977). Data rataan konsumsi wafer dapat dilihat pada Tabel 3.
Analisis sidik ragam menunjukkan penambahan molases sampai level 15\% memberikan hasil yang tidak berbeda nyata $(\mathrm{P}>0,05)$ terhadap konsumsi wafer ransum komplit pada ternak kelinci. Pengaruh yang tidak nyata pada seluruh perlakuan diduga karena penggunaan molases dalam ransum hingga taraf $15 \%$ masih disukai dan tidak mempengaruhi palatabilitas sehingga konsumsi ransum perlakuan relatif sama. Hal ini sejalan dengan pendapat Wahju (2004) yang menyatakan konsumsi ransum dipengaruhi oleh kesehatan ternak, palatabilitas, mutu ransum, tingkat 
produksi dan metode pengelolaannya.

Tabel 3. Konsumsi ransum wafer ransum komplit selama penelitian (g/ekor/minggu)

\begin{tabular}{cc}
\hline Penambahan Molases (\%) & Rataan \pm Stdev \\
\hline 0 & $109,91 \pm 6,53$ \\
5 & $115,97 \pm 3,73$ \\
10 & $199,14 \pm 2,14$ \\
15 & $114,83 \pm 7,51$ \\
\hline
\end{tabular}

Ket : Data yang ditampilkan adalah rataan \pm standar deviasi

Faktor lain yang menyebabkan semua perlakuan relatif sama terhadap konsumsi pakan karena wafer ransum komplit memiliki kandungan protein kasar, lemak kasar dan bahan ekstrak tanpa nitrogen (BETN) yang relatif sama yaitu masingmasing protein kasar 14,23-15,24\%, lemak kasar 1,78-2,87\% dan kandungan BETN $41,83-50,37 \%$ sehingga menyebabkan konsumsi ransum juga relatif sama. Tillman dkk. (1991) menyatakan bahwa ransum yang mempunyai kandungan protein, energi dan bahan kering yang sama akan menyebabkan konsumsi ransum yang sama.

Konsumsi wafer berbahan limbah daun ubi jalar dengan penambahan berbagai level molases pada penelitian ini berkisar 109,91119,14 g/ekor/minggu. Konsumsi wafer berbahan limbah daun ubi jalar dengan penambahan berbagai level molases ini lebih rendah jika dibandingkan dengan penelitian yang dilaporkan oleh Wuysang dkk. (2017), menggunakan kelinci dengan pakan pellet sebesar 127,10-163,80 $\mathrm{g} /$ ekor/minggu serta lebih tinggi dari konsumsi silase dan pellet ransum komplit ternak kelinci yang dilaporkan oleh Rizqiani
(2011), yaitu 92,25-117,78 g/ekor/minggu.

\section{Pertambahan Bobot Badan}

Pertambahan bobot badan kelinci selama penelitian dapat dilihat pada Tabel 4.Berdasarkan analisis sidik ragam menunjukkan bahwa penambahan molases dengan level yang berbeda tidak berbeda nyata $(\mathrm{P}>0,05)$ terhadap pertambahan bobot badan kelinci. Hal ini berarti penggunaan molases hingga taraf $15 \%$ dalam ransum menunjukkan respon yang sama. Hal ini diduga karena konsumsi ransum wafer ransum komplit dalam penelitian ini juga relatif sama sehingga juga memberikan pengaruh yang relatif sama terhadap pertambahan bobot badan. Rasyid (2009), menyatakan bahwa salah satu faktor yang mempengaruhi pertambahan bobot badan adalah konsumsi ransum. Konsumsi ransum dipengaruhi oleh palatabilitas (tingkat kesukaan) ternak tehadap pakan. Pemberian molases hingga taraf 15\% tidak mempengaruhi palatabilas ternak terhadap pakan, sehingga konsumsi ransum juga relatif sama.

Tabel 4. Pertambahan bobot badan kelinci selama penelitian (g/ekor/minggu)

\begin{tabular}{cc}
\hline Penambahan Molases (\%) & Rataan \pm Stdev \\
\hline 0 & $87,44 \pm 2,21$ \\
5 & $94,55 \pm 1,54$ \\
10 & $92,21 \pm 4,85$ \\
15 & $89,50 \pm 5,78$ \\
\hline
\end{tabular}

Ket : Data yang ditampilkan adalah rataan \pm standardeviasi 
Pertambahan bobot badan kelinci yang mengkonsumsi wafer ransum komplit dengan penambahan berbagai level molases ini berkisar 87,44-94,55 g/ekor/minggu. Pertambahan bobot badan kelinci yang mengkonsumsi wafer ransum komplit dengan berbagai level molases pada penelitian ini lebih rendah jika dibandingkan dengan pertambahan bobot badan kelinci yang mengkonsumsi daun ubi jalar dengan penambahan konsentrat yang dilaporkan oleh Tulung dkk. (2018), yaitu 78,40-108,99 g/ekor/minggu, serta lebih rendah dari bobot badan kelinci yang mengkonsumsi pakan berbentuk pellet dilaporkan oleh Wuysang dkk .(2017), yaitu 144,20 - 146,16 g/ekor/minggu.

\section{Konversi Pakan}

Nilai konversi pakan wafer ransum komplit dapat dilihat pada Tabel 5.

Tabel 5. Nilai konversi pakan wafer ransum komplit

\begin{tabular}{cc}
\hline Penambahan Molases (\%) & Rataan \pm Stdev \\
\hline 0 & $1,32 \pm 0,20$ \\
5 & $1,23 \pm 0,06$ \\
10 & $1,31 \pm 0,01$ \\
15 & $1,30 \pm 0,18$ \\
\hline
\end{tabular}

Ket : Data yang ditampilkan adalah rataan \pm standardeviasi

Berdasarkan analisis sidik ragam menunjukkan bahwa penambahan molases sampai level 15\% menunjukkan hasil yang tidak berbeda nyata $(\mathrm{P}>0,05)$ terhadap konversi pakan wafer ransum komplit pada ternak kelinci. Nilai konversi pakan yang tidak berbeda ini diduga berkaitan erat dengan konsumsi dan pertambahan bobot badan kelinci pada penelitian ini tidak berbeda nyata, sehingga berpengaruh pula pada konversi pakan. Hal ini sejalan dengan pendapat Basuki (2002), yang menyatakan bahwa konversi pakan sangat dipengaruhi oleh konsumsi bahan kering dan pertambahan bobot badan ternak. Konversi pakan menggambarkan kualitas suatu pakan, karena nilai suatu pakan ditentukan oleh tingkat konsumsi pakan, dan pertambahan bobot badan (Mujiasih, 2002).

Wicaksono (2007), menyatakan semakin kecil nilai konversi pakan, menunjukkan semakin sedikit pula pakan yang dibutuhkan untuk menghasilkan nilai bobot badan dalam satuan yang sama. Konversi pakan juga digunakan sebagai tolak ukur efisiensi produksi. Tinggi rendahnya angka konversi pakan disebabkan adanya selisih yang semakin besar atau rendah pada perbandingan konsumsi pakan dan pertambahan bobot badan. Angka konversi pakan yang yang tinggi menunjukkan penggunaan pakan yang kurang efisien sebaliknya angka yang mendekati 1 berarti pakan semakin efisien (Mulyono, 2009).

Konversi pakan wafer berbahan limbah daun ubi jalar dengan penambahan berbagai level molases ini lebih baik dibandingkan dengan nilai konversi pakan pellet yang dilaporkan oleh Wuysang dkk. (2017), yaitu 2,82-3,00, serta lebih baik dari konversi pakan daun ubi jalar yang laporkan oleh Tulung dkk. (2017), yaitu 2,93-3,44.

\section{KESIMPULAN}

Pemberian level molases pada wafer ransum komplit hingga $15 \%$ dalam ransum kelinci tidak mampu meningkatkan konsumsi ransum (g/ekor/minggu) dan pertambahan bobot badan (g/ekor/minggu). 


\section{DAFTAR PUSTAKA}

Badan Pusat Statistik Provinsi Riau. 2016. Produksi Tanaman Pangan Menurut Jenis Tanaman Tahun2011-2015. Badan Pusat Statistik. Pekanbaru.

Basuki, P. 2002. Dasar Ilmu Ternak Potong dan Kerja. Bahan Ajar.Fakultas Peternakan Universitas Gadjah Mada. Yogyakarta.

Khalil, M.N. 2016. Sehat Tanpa Obat dengan Ubi Jalar.Cetakan pertama. Andipublished. ISBN 978-979-29-5276-6. Jakarta.

Mujiasih. 2002. Performa Ayam Broiler yang diberi Antibiotik Zine bacitracin, dan Probiotik Bacillus sp dan Berbagai Level Saccharomyces cereviseae dalam Ransumnya. Skripsi. Fakultas Peternakan. Institut Pertanian Bogor. Bogor.

Mulyono, A.M.W. 2009. Nilai Nutritif Onggok Terfermentasi Mutan Trichoderma AAI pada Ayam Broiler. Media Kedokteran Hewan. Fakultas Pertanian Universitas Veteran Bangun Nusantara. Yogyakarta.

Noviagama, V.R. 2002. Penggunaan Tepung Gaplek sebagai Bahan Alternatif dalam Pembuatan Ransum Komplit. Skripsi. Fakultas Peternakan. Institut Pertanian Bogor. Bogor.

NRC. 1997. Nutrient Requirementsof Rabbits. National Academy of Sciences. Washington D.C.

Parakkasi, A. 1999. Ilmu Nutrisi dan Makanan Ternak Ruminan. Universitas IndonesiaPress, Jakarta.

Rasyid, H. 2009. Performa Produksi Kelinci Lokal Jantan padaPemberian Rumput Lapang dan Berbagai Level Ampas Tahu. Skripsi. Fakultas Peternakan. Institut Pertanian Bogor. Bogor.

Retnani, Y.S. Basymeleh dan L. Herawati. 2009. Pengaruh Jenis Hijauan Pakan dan Lama
Penyimpanan terhadap Sifat Fisik Wafer. Jurnal Ilmiah Ilmu-Ilmu Peternakan.12(4):13- 18.

Rizqiani, A. 2011. Performa Kelinci Potong Jantan Lokal Peranakan New Zealand White yang diberi Pakan Silase atau Ransum Komplit. Departemen Ilmu Nutrisi dan Teknologi Pakan. Fakultas Peternakan. Institut Pertanian Bogor. Bogor.

Sarwono, B. dan H.B. Arianto. 2007. Penggemukakan Sapi Potong Secara Cepat Penebar Swadaya. Jakarta.

Tillman, A.D., H. Hartadi, dan S. Reksohadiprodjo. 1991. Tabel Komposisi Pakan untuk Indonesia. Gadjah Mada University Press, Yogyakarta.

Tulung, B, J.F. Umboh dan B.S. Meysi, 2018. Pengaruh Pemanfaatan Daun Ubi Jalar (Ipomoea batatas L) terhadap Performans Ternak Kelinci. Jurnal Zootec. 38(2): 314-319.

Wahju,J. 2004. Ilmu Nutrisi Unggas. Universitas Gajah Mada Press. Yogyakarta.

Wicaksono,P.N. 2007.Pengaruh Campuran Isi Rumen dan Daun Wortel Kering sebagai Pengganti Wheat Pollard terhadap Penampilan Produksi Kelinci New Zealand White.UniversitasBrawijaya.

Wuysang, S., C. Rahasia, J. Umboh, Y. L. R. Tulung. 2017. Pengaruh Penggunaan Molases sebagai Sumber Energi Pakan Penguat dalam Ransum terhadap Pertumbuhan Ternak Kelinci. Jurnal Zootek 37(1): 149-155.

Yusmadi, Nahrowi danM.Ridla 2008. Kajian Mutu Silase dan Hay Ransum Komplit Berbasis Sampah Organik Primer pada Kambing Peranakan Etawah. Agripet 8(1): 3138.

Yudith, T.A. 2010. Pemanfaatan Pelepah Sawit dan Hasil Ikutan Industri Kelapa Sawit terhadap Pertumbuhan Sapi Peranakan Simmental Fase Pertumbuhan. Skripsi. Fakultas Pertanian Universitas Sumatera Utara. Medan. 